\title{
Habitat partitioning by fish larvae among coastal, offshore and frontal zones in the southern North Sea
}

\author{
Franziska Bils ${ }^{1}$, Philipp Kanstinger ${ }^{1}$, Matthias H. F. Kloppmann ${ }^{2, *}$, Myron A. Peck ${ }^{1}$
}

${ }^{1}$ Institute for Hydrobiology and Fisheries Science, Center for Earth System Research and Sustainability, University of Hamburg, Olbersweg 24, 22767 Hamburg, Germany

${ }^{2}$ Institut für Seefischerei, Johann Heinrich von Thünen-Institut, Bundesforschungsinstitut für ländliche Räume, Wald und Fischerei, Palmaille 9, 22767 Hamburg, Germany

\begin{abstract}
This study compared marine and estuarine larval fish assemblages among nearshore, offshore and frontal habitats of the southern North Sea. In late June and early July 2005, parallel cruises collected larvae along offshore transects crossing tidal mixing and river plume frontal zones in the German Bight, and at shallow nearshore stations within the Wadden Sea and associated estuaries of major tributaries. A mixture of larvae from 17 species occurred including the (then) newly re-established 'southern' clupeids (European sardine Sardina pilchardus and anchovy Engraulis encrasicolus) as well as traditional North Sea species such as horse mackerel Trachurus trachurus, solenette Buglossidium luteum and various species of gobies. Multivariate statistics on taxonomic composition indicated that shallow and deep areas were 2 distinct habitats. Wadden Sea stations had a conspicuously different species composition and low species richness compared to all deeper areas. In deeper waters, species composition was similar regardless of frontal strength, and larger larvae occurred most frequently in the cooler areas of the German Bight. Altered species composition observed at some nearshore stations indicated that frontal dynamics and tidal advection may lead to expatriation of larval fish to presumably less favorable areas. Frontal habitats in the German Bight may not necessarily promote higher survival of larval fish than other areas but appear to form important boundaries between species-rich, deeper waters of the German Bight and relatively species-poor, shallower waters of the Wadden Sea.
\end{abstract}

KEY WORDS: Fish larvae $\cdot$ Habitat $\cdot$ Abundance $\cdot$ Distribution $\cdot$ Composition $\cdot$ German Bight

\section{INTRODUCTION}

The German Bight and Wadden Sea regions of the southern North Sea are important nursery areas for the early life stages of a variety of marine fish species (van der Veer et al. 2001, Fox et al. 2008, Baumann et al. 2009). Due to the diverse assemblage of fish species in the region, early life stages can be found yearround with the highest number of species utilizing the late spring and/or early summer period (Greve et al. 2005). For example, the larvae of 42 species were reported in a recent study analyzing year-round catches made at a single location in the German Bight (Malzahn \& Boersma 2007). However, compre- hensive surveys describing larval fish assemblages are surprisingly scarce, and mostly date back to the first half of the past century (e.g. Aurich 1941).

Process-oriented research programs, such as Linking Hydrographic Frontal Activity to Ecosystem (LIFECO) and Global Ocean Ecosystem Dynamics (GLOBEC), have intensively examined ichthyoplankton dynamics at different North Sea habitats, particularly frontal zones. Fronts are common mesoscale hydrographical features in the North Sea that support a high biodiversity of marine fauna including relatively dense aggregations of larval fish, their prey and their predators (Kiørboe et al. 1988, Riegman et al. 1990, Munk 1993, Valenzuela \& Vargas 
2002). Closer to shore, shallow, coastal areas such as the Wadden Sea and associated tributaries and estuaries are known to be important nursery grounds for late larvae and early juveniles of various marine species, particularly flatfishes (Rijnsdorp et al. 1985, van der Veer et al. 2001, Bolle et al. 2009). The objective of the present study was to examine the abundance and species composition of fish larvae occurring in different southern North Sea habitats including (1) nearshore (Wadden Sea) and offshore (German Bight) areas that were either (2) wellmixed, (3) stratified, or (4) frontal zones. The abundance and distribution of larvae were related to physical characteristics of stations, including depth, temperature, salinity and water column stability. The sampling scheme employed here (simultaneous cruises in near- and offshore areas) allows a first glimpse of the habitat utilization by larvae of different species. Knowledge on habitat utilization may help reveal critical habitats for ichthyoplankton as well as pinpoint areas where intra- and interspecific competition exists.

\section{MATERIALS AND METHODS}

\section{Field investigation}

Larval fish were collected between June 28 and July 132005 in the southern North Sea (Fig. 1, and see Appendix 1) as part of stations surveyed during the GLOBEC-Germany and NUTEX (Nutrient Exchange in Semi-Terrestrial Soils) programs. In these surveys, RV 'Alkor' (cruise AL 260) conducted 11 hauls and RV 'Ludwig Prandtl' conducted 25 hauls in the offshore and nearshore area (Appendix 1) using bongo nets with $500 \mu \mathrm{m}$ mesh size and a diameter of $60 \mathrm{~cm}$. Bongo nets were towed at 1 to 3 and 2 to 3 knots, respectively, for 4 to $8 \mathrm{~min}$. The water depths of stations were between 2 and $43 \mathrm{~m}$ (see Kanstinger $\&$ Peck 2009) and at all offshore (deeper water) stations, the water column from 3 to $5 \mathrm{~m}$ above the seabed was sampled using double oblique tows. The volume of water filtered was obtained using internal flowmeters mounted in the mouth of each net. The sample from one of the bongo nets was preserved in

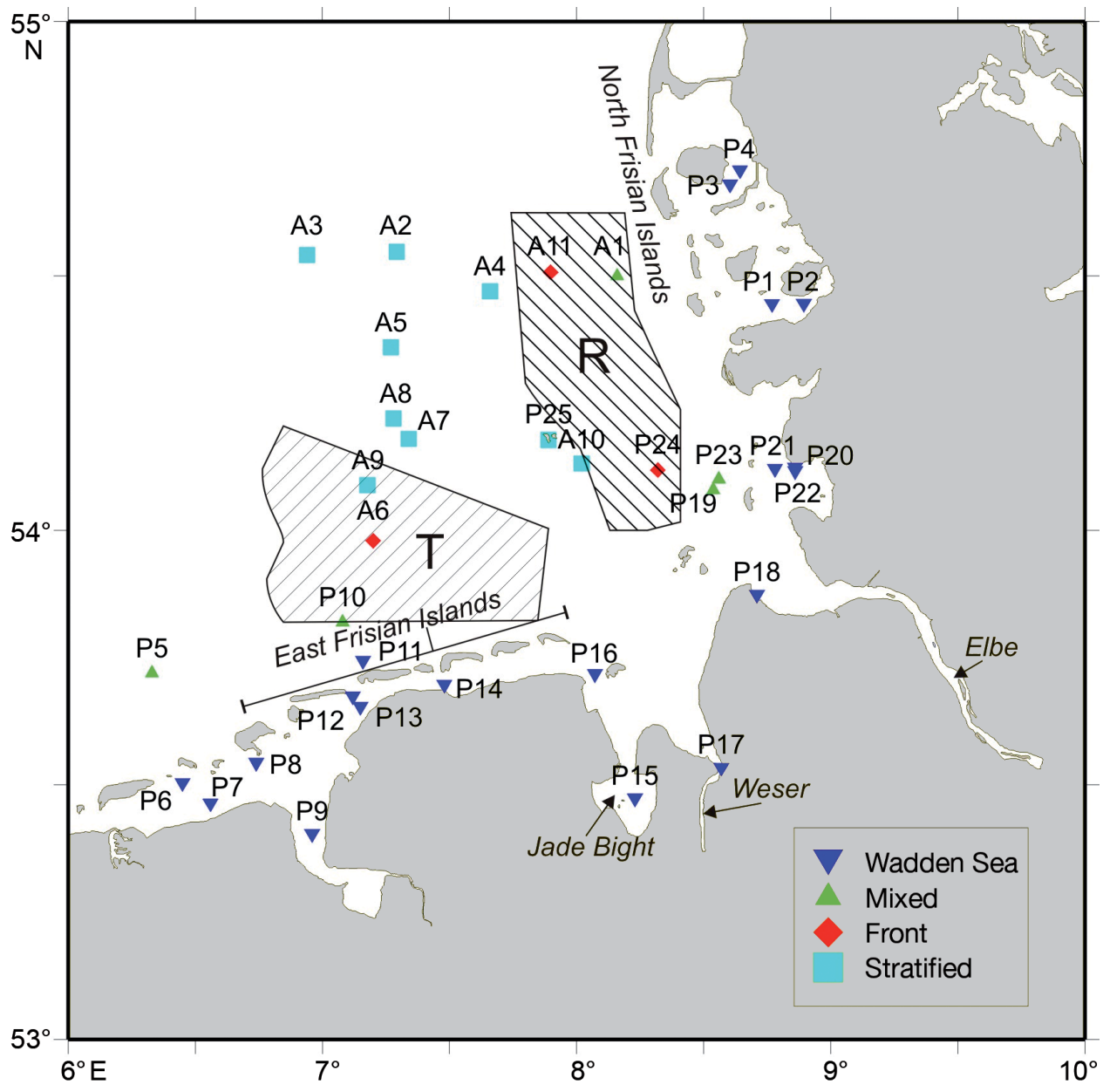

Fig. 1. The position of the sampled stations in the 4 categories: mixed, tidal mixing front, stratified, and Wadden Sea. ID numbers indicate stations sampled by RVs 'Alkor' (A) and 'Ludwig Prandtl' (P). Areas of the German Bight where tidal $(\mathrm{T})$ and river plume $(\mathrm{R})$ fronts occur (after Budéus 1989) are highlighted 
buffered $4 \%$ formalin while the second net sample was used for other purposes (see Kanstinger \& Peck 2009).

Hydrographic measurements at stations sampled by the 'Alkor' were made using a CTD mounted on a Video Plankton Recorder (Seascan) that provided continuous measurements of temperature, salinity, fluorescence and density. The 'Ludwig Prandtl' employed a 'ferry box' that continually recorded surface temperature and salinity and additionally deployed a CTD at 10 stations to record temperature and salinity profiles throughout the whole water column. These in situ measurements were augmented with model-derived, depth-specific estimates of salinity and temperature obtained from the highresolution hydrodynamic model 'BSHcmod' $(900 \mathrm{~m}$ horizontal grid, $z$-coordinate system with 14 depth layers [8 $\mathrm{m}$ at surface]; for full model description and validation, see Dick et al. 2001).

Based upon in situ measurements taken at the time of sampling, stations could be partitioned into 4 different categories: offshore vertically mixed (M), tidal mixing zone, i.e. frontal (F), stratified water (S) and Wadden Sea vertically mixed (W). The first 3 (offshore) categories were based on the stratification parameter $(\phi)$ derived from vertical density $(\rho)$ profiles (Simpson et al. 1979):

$$
\begin{aligned}
& \phi=(1 / h) \int_{-h}^{0}(\rho-\bar{\rho}) g z d z \\
& \bar{\rho}=(1 / h) \int_{-h}^{0} \rho d z
\end{aligned}
$$

where $h$ is the depth of the water column (m), $\rho$ is the density of seawater $\left(\mathrm{kg} \mathrm{m}^{-3}\right)$ at depth $z$ and $g$ is the acceleration due to gravity $\left(\mathrm{m} \mathrm{s}^{-1}\right)$. The value of $\phi\left(\mathrm{J} \mathrm{m}^{-3}\right)$ represents a measure of the amount of energy required to mix the water column and thus increases with increasing water column stratification and equals $<10,10-20$, and $>20 \mathrm{~J} \mathrm{~m}^{-3}$ in mixed, frontal, and stratified waters, respectively (Simpson et al. 1979). The Wadden Sea is a flat-bottomed, high-energy system separated from the North Sea by a row of barrier islands and sandbanks. Deep tidal channels form the connection between the North and Wadden seas. Within the Wadden Sea these channels branch into numerous gullies and creeks. During ebb tides, vast areas of tidal flats emerge and, at low tide, about twothirds of the bottom of the Wadden Sea is exposed. Limits of the Wadden Sea were defined by the $10 \mathrm{~m}$ water depth profile along the German coast offshore of the islands.

\section{Species identification}

In the laboratory, all larvae were identified according to standard literature (Russell 1976, Halbeisen 1988, Munk \& Nielsen 2005) and counted. All larval counts were standardized to numbers $\mathrm{m}^{-2}$ based upon estimates of the volume sampled by nets (Smith \& Richardson 1977).

The standard length (SL) $( \pm 0.05 \mathrm{~mm})$ of the most abundant species, i.e. all undamaged or undistorted larvae of 3 clupeiform species (Sardina pilchardus, Engraulis encrasicolus and Sprattus sprattus) as well as the larvae of horse mackerel Trachurus trachurus and solenette Buglossidium luteum, was measured with an image analysis system (Optimas 6.5). The resulting length distribution was, where necessary, prorated on the entire larval sample. Fish larvae were grouped into 3 size classes (small, medium and large), based upon different length quantiles $(<25 \%$, $25-75 \%$ and $>75 \%$ ) for each species (Table 1 ). No attempts were made to correct for larval shrinkage during preservation.

\section{Data analysis}

All multivariate statistics were conducted with the PRIMER 6 software package (Clarke \& Gorley 2006). Species composition at stations in the pre-defined areas was analyzed for similarities with the SIMPER (similarity percentages) procedure. Multi-dimensional-scaling (MDS) ordination was utilized to group stations of similar species composition. To do this, a similarity matrix was calculated based upon abundance of all species for those stations. Different similarity indices can be utilized to achieve this. We employed the Bray-Curtis coefficient, which is most commonly used for ecological purposes (Clarke \& Warwick 2001). In ecological studies, the Bray-Curtis coefficient has several advantages over many other similarity/dissimilarity coefficients of which the most important are: it is independent of scale, and joint
Table 1. Larval size classes (mm) of 5 marine fish species utilized in this study

\begin{tabular}{|lccccc|}
\hline Size class & $\begin{array}{c}\text { Sardina } \\
\text { pilchardus }\end{array}$ & $\begin{array}{c}\text { Sprattus } \\
\text { sprattus }\end{array}$ & $\begin{array}{c}\text { Engraulis } \\
\text { encrasicolus }\end{array}$ & $\begin{array}{c}\text { Trachurus } \\
\text { trachurus }\end{array}$ & $\begin{array}{c}\text { Buglossidium } \\
\text { luteum }\end{array}$ \\
\hline $\begin{array}{l}\text { Small }(<25 \% \\
\text { quartile) }\end{array}$ & $<7.8$ & $<7.3$ & $<4.6$ & $<2.9$ & $<2.9$ \\
$\begin{array}{l}\text { Medium }(25-75 \% \\
\text { quantile) }\end{array}$ & 7.8 to $<10.6$ & 7.3 to $<9.9$ & 4.6 to $<6.3$ & 2.9 to $<4.1$ & 2.9 to $<4.6$ \\
$\begin{array}{l}\text { Large }(>75 \% \\
\text { quartile) }\end{array}$ & $\geq 10.6$ & $\geq 9.9$ & $\geq 6.3$ & $\geq 4.1$ & $\geq 4.6$ \\
\hline
\end{tabular}


absences of species on stations have no effect on the coefficient (Clarke \& Warwick 2001). In order to reduce the impact of the most abundant species, values of abundance were square-root transformed.

The resulting species-similarity matrix was visualized using a 2-dimensional MDS plot. A stress value was also calculated for the ordination in order to judge the quality of the plot. Stress values $<0.1$ indicate good representation of the similarity matrix and a low potential of misinterpretation, values $<0.2$ still allow useful interpretation, whereas stress values $>0.2$ indicate interpretations that should be treated with caution. Cluster analysis was carried out in order to identify groups of stations that aggregated at the same level of similarity. The major similarity levels were later used to visualize these stations groups in the MDS plot. Subsequently, taxa that contributed most to the overall structure of the similarity matrix were determined using the BVSTEP procedure in PRIMER 6.

\section{RESULTS}

\section{Hydrography}

Sea surface temperatures were between $<15^{\circ} \mathrm{C}$ (min. $14.6^{\circ} \mathrm{C}$ ) in the inner German Bight and $>20^{\circ} \mathrm{C}$ (max. $22.8^{\circ} \mathrm{C}$ ) in the estuarine areas. There was a core of cooler surface waters $<15.5^{\circ} \mathrm{C}$ in the central German Bight surrounded by warmer coastal and
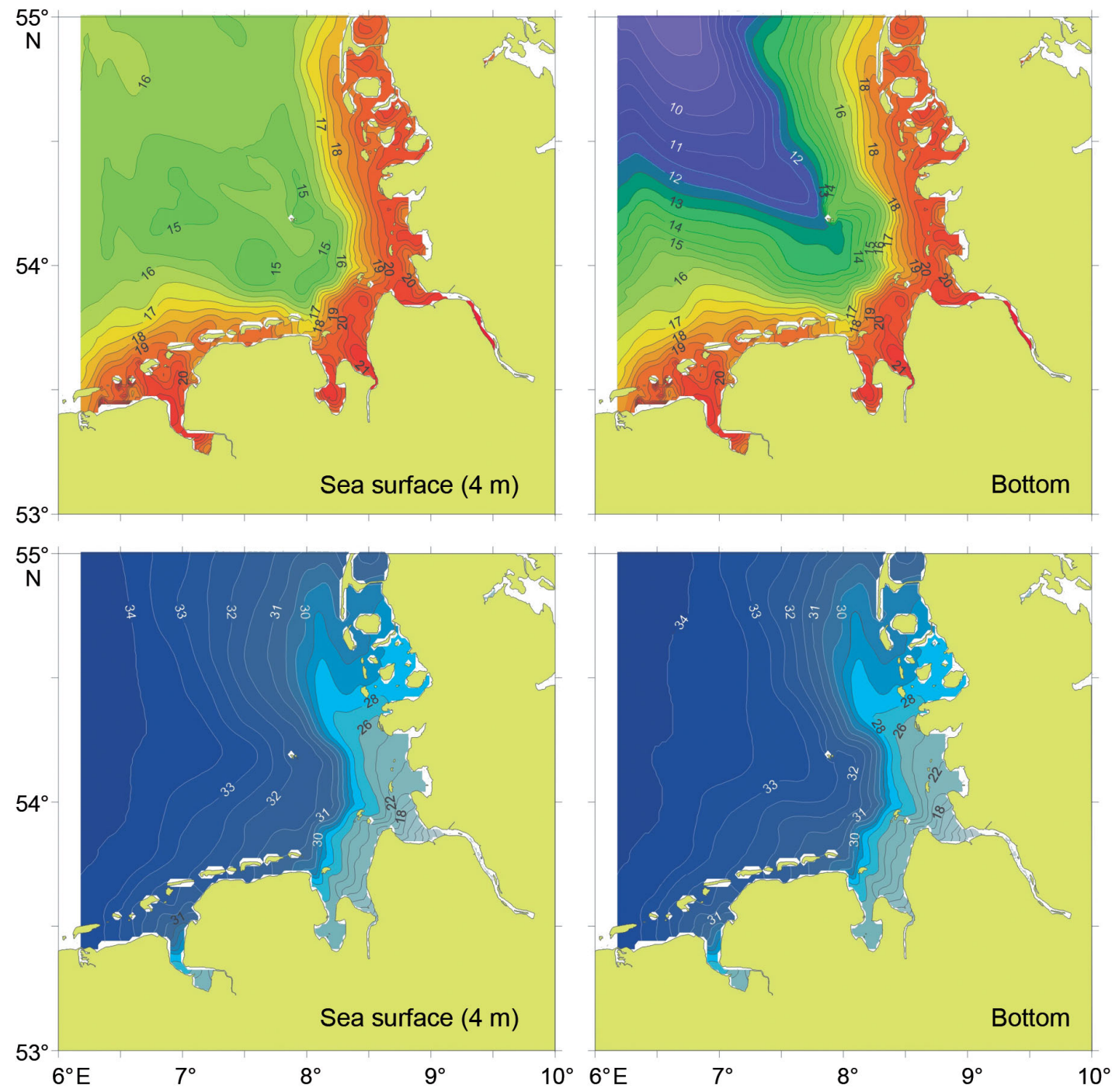

Fig. 2. Mean temperatures (upper panels) and salinities (lower panels) in the sea surface and close to the bottom during the sampling period. Temperatures and salinities were estimated from the operational circulation model 'BSHcmod' (see 'Materials and methods'). 
northwestern offshore waters (Fig. 2), while bottom temperatures were $<10^{\circ} \mathrm{C}\left(\min .8 .7^{\circ} \mathrm{C}\right)$ in the northwestern and deeper areas of the German Bight and $>20^{\circ} \mathrm{C}\left(\max .22 .8^{\circ} \mathrm{C}\right)$ in the shallow estuarine areas (Fig 2). Surface- as well as bottom-water salinity had a more or less west-to-east gradient from values $>34$ (max. 34.3) in the west to $<30$ ( $\mathrm{min} .28 .4$ ) in the east at the North Frisian coast (Fig 2). Warm coastal waters and the cooler offshore waters were separated by distinct fronts north of the East Frisian and west of the North Frisian Islands. The frontal structures parallel to the coast were more pronounced in the bottom layer than in the surface layer revealing thermal stratification in areas north and west of the fronts. In the thermally stratified areas bottom salinities were higher than in the surface.

The frontal structures show the typical characteristics for the German Bight and can be separated into 2 distinct types. First, a tidal mixing front occurred parallel to the East Frisian Islands and extended to the western margin of the Jade Bight. This first front separated stratified and cooler offshore waters from well mixed and warmer coastal waters. Second, a river plume front separated distinctly fresher waters originating from the rivers of Weser and Elbe from the more saline offshore waters. This second front was parallel to the North Frisian Islands between the western margins of the Jade Bight up to the island of Sylt ( $\left.54^{\circ} 55^{\prime} \mathrm{N}, 8^{\circ} 18^{\prime} \mathrm{E}\right)$.

\section{Fish larvae distribution}

A total of 9415 fish larvae was found, of which 436 $(4.7 \%)$ could not be identified because they were too badly damaged.

Table 2. Abundance (no. of fish $\mathrm{m}^{-2}$ ) of larval fish species at each station. $(\mathrm{CG})=$ included in Clupeiform general category

\begin{tabular}{|c|c|c|c|c|c|c|c|c|c|c|c|c|c|c|c|c|c|}
\hline 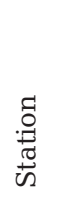 & 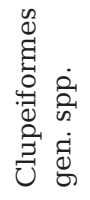 & 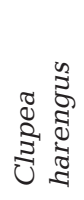 & 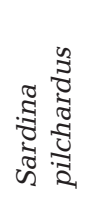 & 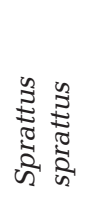 & 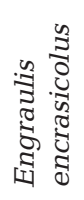 & 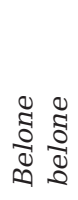 & 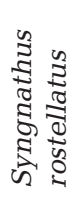 & 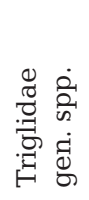 & 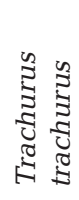 & 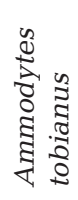 & 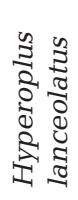 & 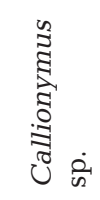 & 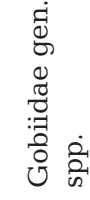 & 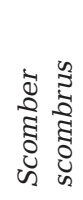 & 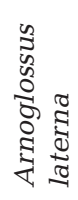 & 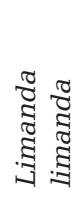 & 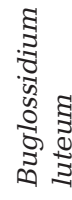 \\
\hline A1 & 4.1 & 0.0 & $(\mathrm{CG})$ & (CG) & (CG) & 0.0 & 0.5 & 0.0 & 0.0 & 0.0 & 0.0 & 14.0 & 8.8 & 0.0 & 0.5 & 0.5 & 1.6 \\
\hline A2 & & 0.0 & 27.5 & 6.6 & 0.0 & 0.0 & 0.0 & 0.0 & 1.2 & 0.0 & 0.0 & 3.1 & 4.3 & 0.0 & 1.2 & 20.5 & 6.2 \\
\hline A3 & & 0.0 & 33.0 & 39.2 & 0.0 & 0.0 & 0.0 & 0.7 & 0.9 & 0.0 & 0.0 & 0.7 & 2.1 & 2.1 & 0.7 & 4.5 & 7.3 \\
\hline A4 & & 0.0 & 17.8 & 13.2 & 0.0 & 0.0 & 0.0 & 1.4 & 5.0 & 0.0 & 0.0 & 25.5 & 45.5 & 0.6 & 4.4 & 11.1 & 21.6 \\
\hline A5 & & 0.0 & 122.5 & 13.9 & 0.0 & 0.0 & 0.0 & 0.0 & 21.9 & 0.0 & 0.0 & 9.0 & 14.5 & 1.6 & 17.1 & 0.0 & 8.2 \\
\hline A6 & & 0.0 & 57.3 & 3.6 & 0.0 & 0.0 & 0.0 & 0.0 & 22.4 & 0.0 & 0.0 & 31.6 & 12.9 & 3.4 & 2.8 & 3.7 & 55.1 \\
\hline A7 & & 2.6 & 130.6 & 25.7 & 0.0 & 0.0 & 0.0 & 1.3 & 61.9 & 1.3 & 1.3 & 45.4 & 7.7 & 6.4 & 5.2 & 44.2 & 56.7 \\
\hline A8 & & 0.0 & 52.1 & 8.6 & 0.0 & 0.0 & 0.0 & 0.6 & 20.8 & 0.0 & 0.0 & 3.6 & 4.1 & 0.6 & 1.2 & 6.5 & 7.8 \\
\hline A9 & & 0.0 & 98.2 & 63.1 & 0.0 & 0.0 & 0.0 & 0.0 & 13.7 & 0.0 & 0.0 & 3.7 & 4.6 & 0.9 & 7.3 & 6.4 & 35.7 \\
\hline A10 & & 0.0 & 10.3 & 9.2 & 0.0 & 0.0 & 0.0 & 0.0 & 4.8 & 0.0 & 0.0 & 1.6 & 2.6 & 0.5 & 4.2 & 1.1 & 12.1 \\
\hline A11 & & 0.0 & 8.0 & 0.0 & 0.0 & 0.0 & 0.3 & 0.0 & 0.6 & 0.0 & 0.0 & 19.1 & 20.5 & 0.0 & 0.3 & 0.6 & 9.5 \\
\hline P1 & & 0.0 & 0.0 & 0.0 & 0.0 & 0.0 & 0.4 & 0.0 & 0.0 & 0.0 & 0.0 & 0.4 & 0.0 & 0.0 & 0.0 & 0.0 & 0.0 \\
\hline P2 & & 0.0 & 0.0 & 0.0 & 0.0 & 0.0 & 0.1 & 0.0 & 0.0 & 0.0 & 0.0 & 0.0 & 3.0 & 0.0 & 0.0 & 0.0 & 0.0 \\
\hline P3 & & 0.0 & 0.0 & 0.0 & 0.0 & 0.0 & 0.0 & 0.0 & 0.0 & 0.0 & 0.0 & 0.2 & 1.4 & 0.0 & 0.0 & 0.0 & 0.0 \\
\hline P4 & & 0.0 & 0.0 & 0.0 & 0.1 & 0.0 & 2.6 & 0.0 & 0.0 & 0.0 & 0.0 & 0.0 & 2.9 & 0.0 & 0.0 & 0.0 & 0.0 \\
\hline P5 & & 0.0 & 22.4 & 4.2 & 0.0 & 0.0 & 0.0 & 0.0 & 28.4 & 0.0 & 0.0 & 18.1 & 17.5 & 2.4 & 28.4 & 0.0 & 27.2 \\
\hline P6 & & 0.0 & 0.0 & 0.0 & 0.0 & 0.0 & 0.1 & 0.0 & 0.0 & 0.0 & 0.0 & 0.0 & 1.6 & 0.0 & 0.0 & 0.0 & 0.0 \\
\hline P7 & & 0.0 & 0.0 & 0.0 & 0.0 & 0.0 & 0.0 & 0.0 & 0.0 & 0.0 & 0.0 & 0.0 & 0.8 & 0.0 & 0.0 & 0.0 & 0.0 \\
\hline P8 & & 0.0 & 0.0 & 2.1 & 0.0 & 0.2 & 10.7 & 0.0 & 0.0 & 0.0 & 0.0 & 0.0 & 4.8 & 0.0 & 0.0 & 0.0 & 0.0 \\
\hline P9 & & 0.0 & 0.0 & 0.1 & 0.0 & 0.0 & 0.3 & 0.0 & 0.0 & 0.0 & 0.0 & 0.0 & 9.7 & 0.0 & 0.0 & 0.0 & 0.0 \\
\hline P10 & & 0.0 & 3.4 & 5.6 & 4.5 & 0.0 & 0.0 & 4.7 & 49.2 & 0.0 & 0.0 & 7.4 & 31.0 & 0.0 & 8.8 & 0.0 & 23.6 \\
\hline P11 & & 0.0 & 0.0 & 0.0 & 4.5 & 0.0 & 0.0 & 0.0 & 0.2 & 0.0 & 0.0 & 0.0 & 0.2 & 0.0 & 0.0 & 0.0 & 0.0 \\
\hline P12 & & 0.0 & 0.0 & 0.0 & 0.0 & 0.0 & 0.4 & 0.0 & 0.0 & 0.0 & 0.0 & 0.0 & 10.1 & 0.0 & 0.0 & 0.0 & 0.0 \\
\hline P13 & & 0.0 & 0.0 & 0.0 & 0.0 & 0.0 & 0.2 & 0.0 & 0.0 & 0.0 & 0.0 & 0.0 & 11.6 & 0.0 & 0.0 & 0.0 & 0.0 \\
\hline P14 & & 0.0 & 0.0 & 0.4 & 6.3 & 0.0 & 0.0 & 0.0 & 5.0 & 0.0 & 0.0 & 0.0 & 1.1 & 0.0 & 0.4 & 0.0 & 0.0 \\
\hline P15 & 1.8 & 0.0 & (CG) & (CG) & (CG) & 0.0 & 1.4 & 0.0 & 0.0 & 0.0 & 0.0 & 0.0 & 72.7 & 0.0 & 0.0 & 0.0 & 0.0 \\
\hline P16 & & 0.0 & 0.6 & 0.9 & 0.0 & 0.0 & 0.6 & 0.0 & 0.0 & 0.0 & 0.0 & 0.0 & 30.7 & 0.0 & 0.0 & 0.0 & 0.0 \\
\hline P17 & & 0.0 & 0.0 & 0.0 & 0.0 & 0.0 & 0.0 & 0.0 & 0.0 & 0.0 & 0.0 & 0.0 & 0.0 & 0.0 & 0.0 & 0.0 & 0.0 \\
\hline P18 & & 0.0 & 6.8 & 1.7 & 0.9 & 0.0 & 0.4 & 0.0 & 4.5 & 0.0 & 0.0 & 2.7 & 3.6 & 0.0 & 0.4 & 0.0 & 2.7 \\
\hline P19 & & 0.0 & 1.0 & 0.4 & 0.2 & 0.0 & 0.6 & 0.0 & 0.3 & 0.0 & 0.0 & 0.3 & 0.7 & 0.0 & 0.1 & 0.0 & 0.1 \\
\hline P20 & & 0.0 & 0.0 & 0.0 & 0.0 & 0.0 & 0.6 & 0.0 & 0.0 & 0.0 & 0.0 & 0.0 & 4.7 & 0.0 & 0.0 & 0.0 & 0.0 \\
\hline P21 & & 0.0 & 0.0 & 0.0 & 0.0 & 0.0 & 1.6 & 0.0 & 0.0 & 0.0 & 0.0 & 0.0 & 5.6 & 0.0 & 0.0 & 0.0 & 0.0 \\
\hline P22 & & 0.0 & 0.0 & 0.0 & 0.0 & 0.0 & 1.1 & 0.0 & 0.0 & 0.0 & 0.0 & 0.0 & 10.5 & 0.0 & 0.0 & 0.0 & 0.0 \\
\hline P23 & & 0.0 & 0.0 & 0.0 & 0.0 & 0.0 & 0.4 & 0.0 & 0.0 & 0.0 & 0.0 & 0.0 & 11.2 & 0.0 & 0.0 & 0.0 & 0.0 \\
\hline P24 & & 0.0 & 0.0 & 0.0 & 0.0 & 0.0 & 0.7 & 0.0 & 0.0 & 0.0 & 0.0 & 0.0 & 11.1 & 0.0 & 0.0 & 0.3 & 0.0 \\
\hline P25 & & 0.0 & 31.4 & 14.3 & 0.0 & 0.0 & 0.0 & 0.7 & 46.0 & 0.0 & 0.0 & 12.6 & 5.1 & 2.7 & 17.4 & 0.0 & 29.6 \\
\hline
\end{tabular}


Fish larvae were grouped into 16 different taxa (Table 2). Identification of sprat and sardine was difficult because these 2 species bear a close resemblance in terms of body shape and pigmentation, and both were often damaged during capture. Separation of these 2 species by myomere count was not possible in $56 \%$ of all larvae because the gut was detached from the anus region, particularly in relatively small (4 to $8 \mathrm{~mm}$ SL) larvae. At most stations enough clupeids (i.e. $>30 \%$ or alternatively $>100$ specimens) could be determined to the species level; in these cases the relative composition of all clupeids was prorated to the relative composition of undamaged clupeid larvae. At one station (A11) only 3 of 27 clupeids could be identified to species (sardine). The potential mixture of larvae of sprat, sardine and anchovy, of which too badly damaged specimens could be easlily confused with the former 2 species, were placed within an 'unidentified clupeids' category. Two stations contained only damaged clupeid larvae in fairly low numbers and these stations were excluded from further statistical analyses.

Gobies (Gobiidae), gurnards (Triglidae) and dragonets (Callionymus) could not be identified to species because they were in an early developmental stage lacking distinguishing features when both sampled the same station. The coastal stations contained only 1 to 5 taxa with the exception of 1 station in the Elbe estuary (9 taxa). Diversity was higher in the offshore area, particularly outside the tidal and river plume fronts, where between 7 and 13 taxa were found per station. Larval fish abundance was much higher at stations further away from the coast than at inshore ones.

Larvae of sardine were the most numerous with a mean $( \pm \mathrm{SD})$ abundance of $18.3 \pm 34.9$ larvae $\mathrm{m}^{-2}$, followed by goby $(10.5 \pm 14.5)$, solenette $(8.5 \pm 15.2)$, horse mackerel $(8.0 \pm 15.7)$, sprat $(6.3 \pm 13.1)$ and dragonet (5. $5 \pm 10.5$ ). These 6 species constituted $90.2 \%$ of the total mean larval fish abundance. Goby larvae were the only group that occurred throughout the investigated area, while all other species were more abundant in specific habitat. Larvae of anchovy, lesser pipefish Syngnathus rostellatus and of the garfish Belone belone were found almost exclusively in the $\mathrm{M}$ and $\mathrm{W}$ stations. The larvae of all other species were only found in more saline (salinity $\geq 30$ ) conditions at offshore stations; these included scaldfish Arnoglossus laterna, mackerel Scomber scombrus, horse mackerel Trachurus trachurus, and (with the exception of 1 station) also dragonet Callionymus sp. (Fig. 3).

\section{Larval fish assemblages}

SIMPER analysis showed that the pre-defined groups (, F M and W) had different grades of between-station similarity. Highest between-station similarity was given for $\mathrm{S}$ stations with $67.8 \%$ similarity followed by the $\mathrm{W}$ stations with an average similarity of $43.5 \%$. F and $M$ stations had a comparatively low similarity with $39.5 \%$ and $31.9 \%$, respectively. The species that contributed the most $(>90 \%)$ to between-station similarities were sardine, sprat, horse mackerel, solenette, gobies, dragonet, scaldfish and dab for S stations, gobies, dragonet, solenette, dab, and sardine for F stations, gobies, horse mackerel, solenette, sardine, dragonet, lesser pipefish, and scaldfish for $M$ stations, and gobies and pipefish for the W stations. Cluster analysis showed that there were 3 distinct station clusters at minimum similarity of $>37 \%$. Further sub-groups were distinguished at $>51 \%$ and at $>62 \%$. MDS ordination shows those 3 distinct station clusters at a species similarity index of $\geq 37 \%$ and a stress value of 0.09 (Fig. 4) but these clusters did not necessarily correspond to station types previously defined using hydrography. For example, all of the $\mathrm{S}$ and most of the $\mathrm{W}$ stations were separated into 2 larger groups ( $\geq 51 \%$ similarity). Among the M-stations, P5 and P10 were within the stratified cluster, P23 was within with the Wadden Sea group, and P19 was clustered ( $\geq 37 \%$ similarity) with $2 \mathrm{~W}$ stations, P14 and $\mathrm{P} 11$. One $\mathrm{M}$ station (P17) was excluded from the analysis because it contained no fish larvae. Two F stations (A6 \& A11) were in the offshore station group while the other F station (P24) was within one Wadden Sea group ( $\geq 51 \%$ similarity). Surprisingly, the larval fish composition of one W station (P18) was highly similar $(>62 \%)$ to that of an F station (A11) and was $\geq 51 \%$ similar to all offshore stations. This station contained 9 larval fish species which were normally found further offshore, such as sardine, sprat, horse mackerel, dragonet and solenette (Table 2) as well as species typical for the Wadden Sea such as pipefish and gobies. One station (P1) was completely separate from all other stations; it contained only 2 species (Syngnathus rostellatus and Callionymus sp.) in relatively low abundance. Application of the BVSTEP routine indicated that variability in the larval abundance of sprat, horse mackerel, solenette, gobies, and lesser pipefish had the highest influence on the clustering of stations based upon species similarity matrix. 

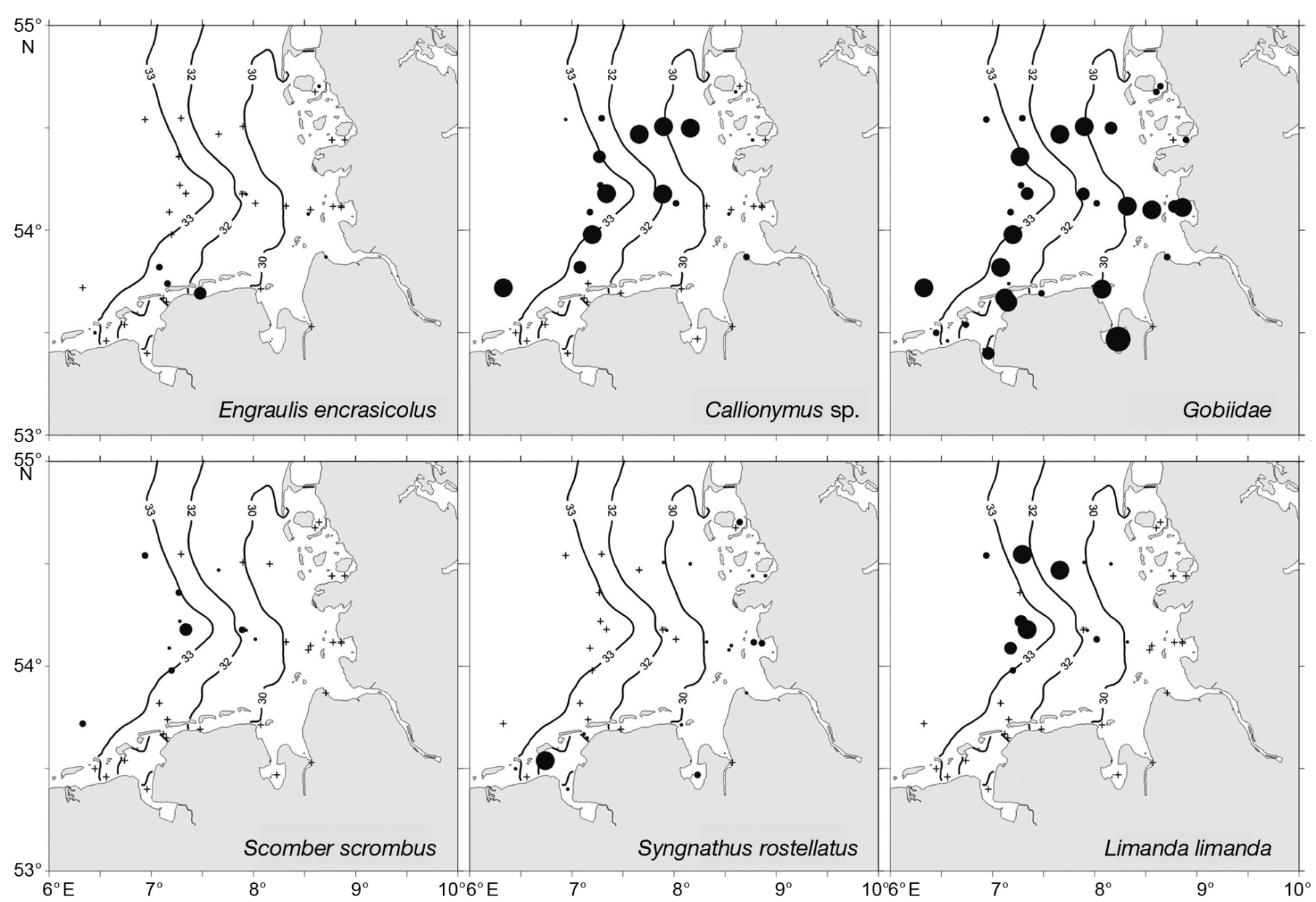

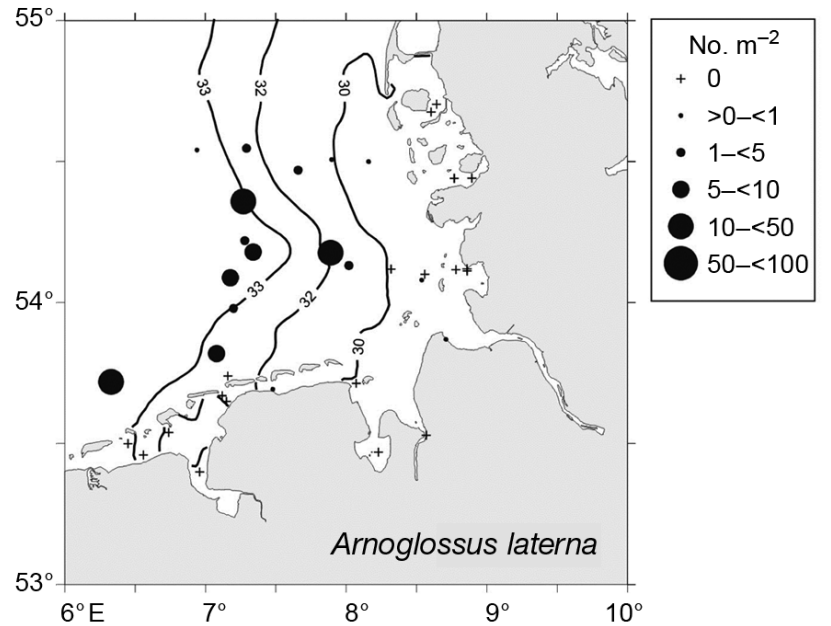

\section{Length distribution of larvae}

For all analyzed species, with the exception of anchovy, the medium size class $(25-75 \%$ quantile of length measurements) showed the highest degree of dispersion. The small $(<25 \%)$ and the large $(>75 \%)$ size classes showed a more restricted range of occurrence (Figs. 5 \& 6).
Fig. 3. Abundance of larval taxa frequently encountered at offshore stations. The isohalines of selected salinity levels at the sea surface are also shown

\section{Sardina pilchardus}

Sardine larvae were between 5.5 and $20.0 \mathrm{~mm} \mathrm{SL}$ with the majority of larvae being 7.5 to $11.5 \mathrm{~mm}$ SL. The smallest sardine larvae were most abundant in stratified, offshore waters where salinities exceeded 33 (Fig 5). In less saline waters, relatively small sardine larvae were scarce. Medium-sized sardine larvae were most common in stratified areas but also occurred in a few $\mathrm{M}$ and $\mathrm{W}$ stations. The largest larvae, again, seemed to be more abundant in the more saline (>33) waters of the central German Bight. Only $3 \mathrm{M}$ and $\mathrm{W}$ stations contained sardine larvae: P10, south of the tidal mixing front; P18, in the Elbe estuary; P19, east of the river plume front.

\section{Sprattus sprattus}

Sprat larvae were between 5.0 and $16.5 \mathrm{~mm}$ SL with most of the larvae between 6.5 and $11.5 \mathrm{~mm}$ SL. The 


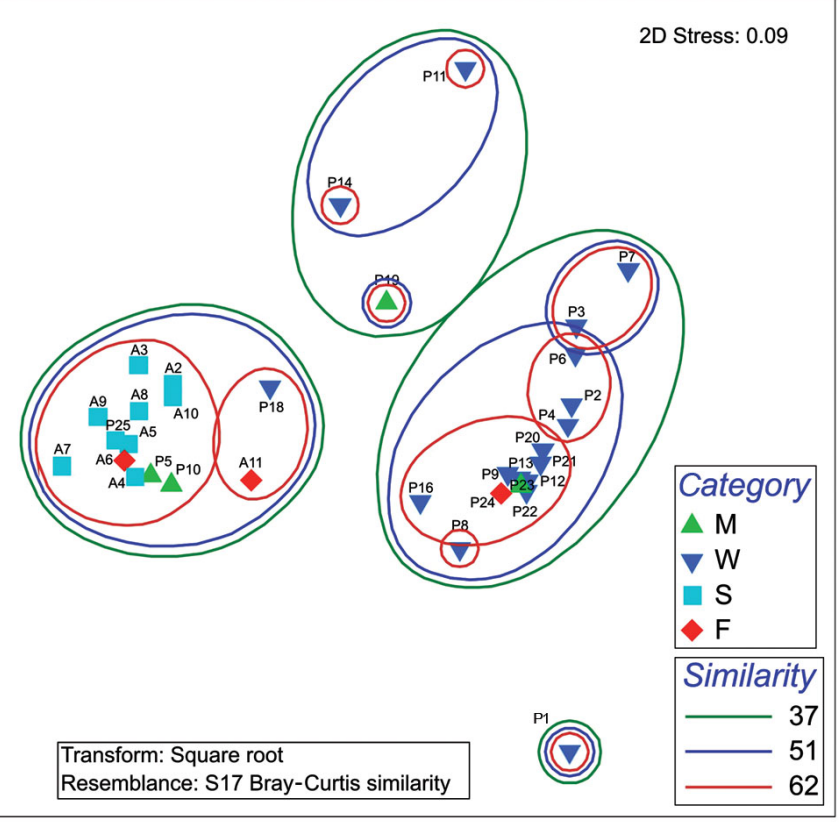

Fig. 4. MDS ordination of the species similarity matrix based on taxon abundances at the 4 station categories: mixed (M), tidal mixing front (F), stratified (S), and Wadden Sea (W). Grouping levels were chosen according to cluster analysis results peak length classes were 7.5 and $9.5 \mathrm{~mm}$ SL. As with sardine, sprat larvae were more likely to be found in the stratified and saline areas of the German Bight at salinities >33. Also, mediumsized larvae were primarily dispersed across stratified areas. However, the largest larvae were more commonly found in the more saline (>33) waters in the west (Fig. 5).

\section{Engraulis encrasicolus}

Anchovy larvae were 3.5 to $9.0 \mathrm{~mm}$ SL with most $<7.0 \mathrm{~mm}$ SL. The larvae occurred only in few $M$ and $W$ stations and showed no conspicuous change in distribution with changes in SL (Fig. 3).

\section{Trachurus trachurus}

Larvae of horse mackerel were between 2.0 and $9.0 \mathrm{~mm}$ SL and exhibited a distinct peak at $3.5 \mathrm{~mm}$ SL. The smallest larvae were most commonly encountered at salinities $>32$. The highest abundance occurred at the mixed and

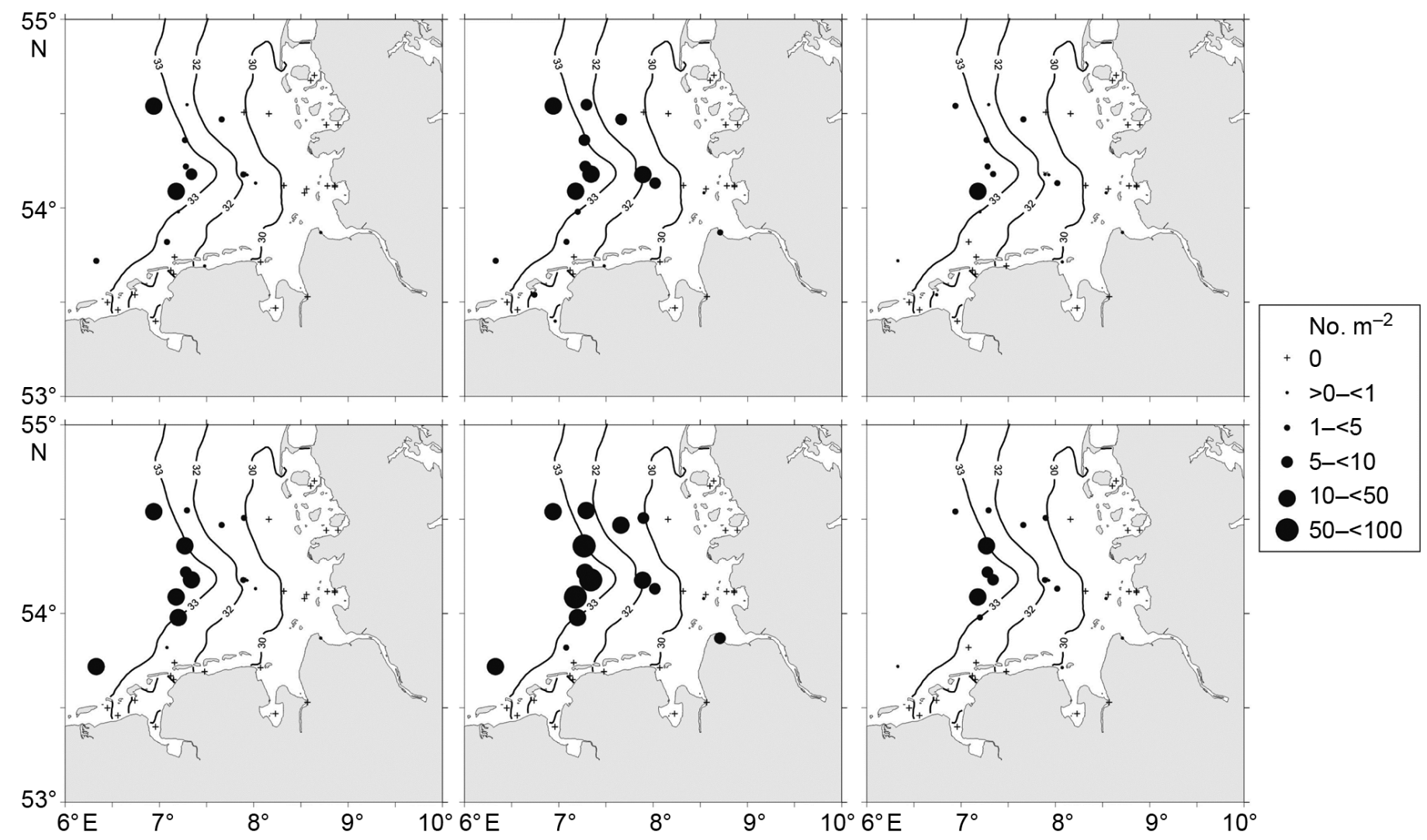

Fig. 5. Sprattus sprattus and Sardina pilchardus. Abundance of sprat (top) and sardine (bottom) larvae of the different length classes: small (left), medium sized (middle) and large (right), corresponding to the $<25,25-75$, and $>75 \%$ measurement quantiles, respectively. Isohalines of selected salinity levels at the sea surface are also shown 

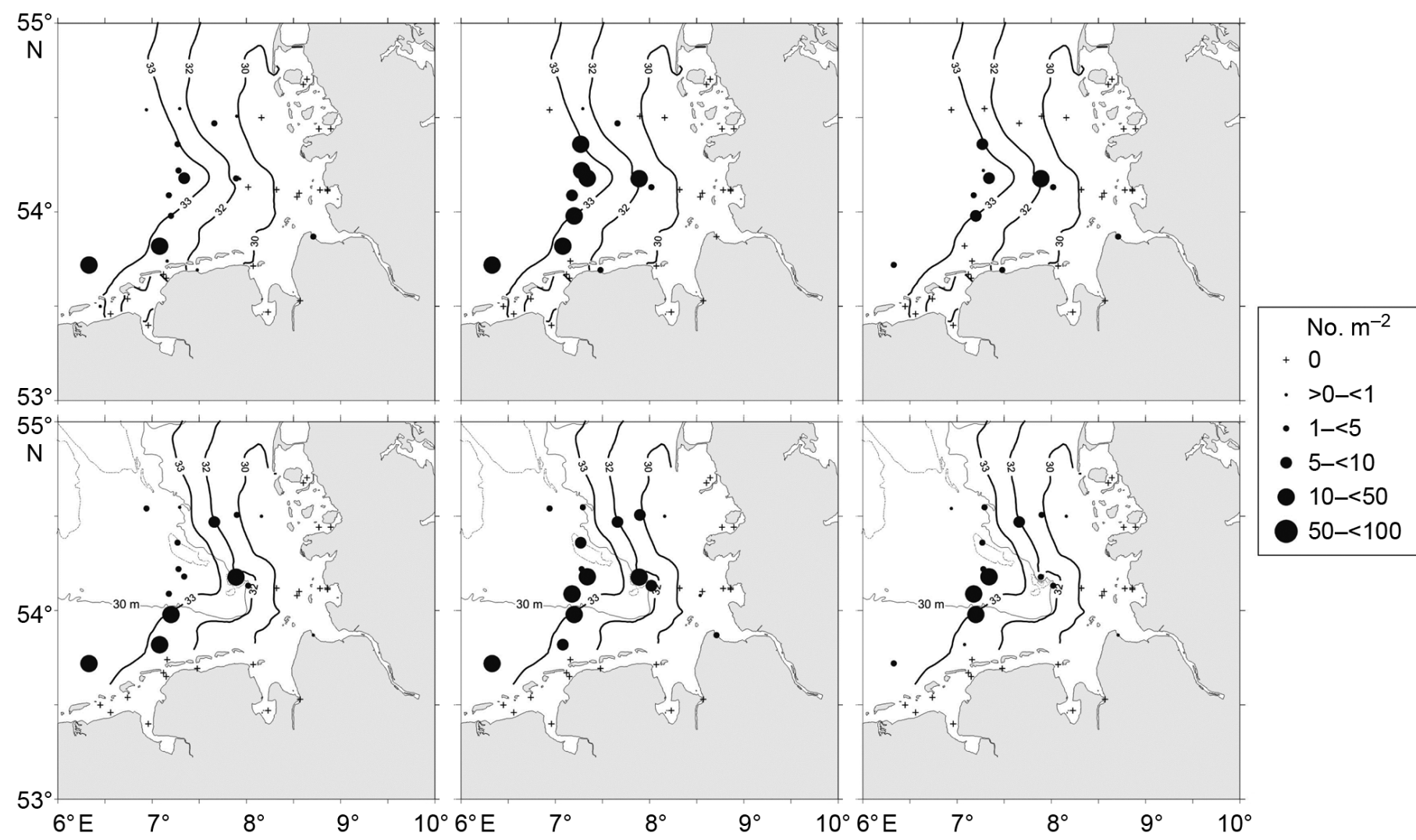

Fig. 6. Trachurus trachurus and Buglossidium luteum. Abundance of horse mackerel (top) and solenette (bottom) larvae of the different length classes: small (left), medium-sized (middle) and large (right), corresponding to the $<25,25-75$, and $>75 \%$ measurement quantiles, respectively. The $30 \mathrm{~m}$ depth contours are shown, as well as isohalines of selected salinity levels: at the sea surface for horse mackerel and at the bottom for solenette

warmer side of the tidal mixing front. Medium-sized horse mackerel larvae appeared to be distributed across the entire stratified area while the largest larvae seemed to concentrate in the cooler central part of the stratified waters of the German Bight (Fig. 6).

\section{Buglossidium luteum}

Solenette larvae were between 2.0 and $8.0 \mathrm{~mm} \mathrm{SL}$, with a peak in the $3.0 \mathrm{~mm}$ length class. The smallest larvae were found in areas where bottom salinity was $\geq 32$ and depth was $<30 \mathrm{~m}$. Medium-sized solenette larvae were spread across the stratified area and were more numerous in the cooler waters in the central German Bight (Fig. 6). Large solenette larvae were most numerous at 3 stations immediately adjacent to the tidal front (Fig 6).

\section{DISCUSSION}

Given the importance of the southern North Sea as a nursery ground for various species of marine fish, it is surprising that so few studies have conducted simultaneous sampling for larval fish in both near- and offshore areas. Most studies using a sampling scheme comparable to the present study in this region were conducted decades ago (Aurich 1941, 1953) and/or focused on specific species (Bückmann 1950). In those earlier studies, nearshore sampling was also restricted to estuaries of larger rivers, and no study surveyed shallow areas of the Wadden Sea. Naturally, our efforts to understand habitat partitioning by fish early life stages must be viewed in light of the effectiveness with which larvae were sampled using bongo gear (see Somerton \& Kobayashi 1989) and the time period of our sampling. Despite differences in tow speed, the species composition and length distributions of larvae captured using the RVs 'Prandtl' and 'Alkor' were similar when both sampled the same station, providing confidence in our ability to compare among the different habitats. Secondly, the present survey provided only a snapshot in time of a larval fish assemblage (in June and July) that exhibits seasonal changes (Greve et al. 2005, Malzahn \& Boersma 2007) and interannual differences (Munk et al. 1999). Nonetheless, our sampling captured the spawning season of a number of ecologically important species including newly re-established members of the North Sea fish community, anchovy and sar- 
dine, and a clear partitioning was found in species using near- and offshore areas.

Our comparison of near- and offshore habitats in the German Bight was based upon ichthyoplankton samples using bongo nets. While bongo nets are considered to efficiently sample young larvae of most fish species (Smith \&d Richardson 1977), a few species that typically occur in the summer months in this region may have been missed by this sampling gear. For example, Nellen \& Hempel (1970) conducted a summer field survey of this region and reported that larvae of the lesser weaver Echiichtys vipera, grey mullets (Mugilidae spp.), and striped mullet Mullus surmuletus were ichthyoneuston (i.e. larvae that may exclusively occur within the surface/upper $30 \mathrm{~cm}$ of the water column). Other studies report that the larvae of the gar pike Belone belone may also be found only at these shallow depths (John 1983). Furthermore, older stages of mackerel and horse mackerel display considerable preference for this layer while smaller conspecifics prefer deeper layers (Kloppmann 1994, Hillgruber \& Kloppmann 2001, Kloppmann et al. 2001). Only one gar pike larva and no larvae of grey mullets were captured in the nearshore areas where they typically occur (Wheeler 1969, John 1983). Therefore, we conclude that the results presented here represent typical larval summer assemblages susceptible to capture by depth-integrating plankton nets while typical inhabitants of the surface layer were underrepresented. Future investigations, particularly of the nearshore areas, should consider using neuston nets in order to fully investigate larval fish assemblages in those areas.

Differences in the ichthyoplankton species composition and abundance suggest that, in some cases, habitat partitioning could be described by differences in water mass characteristics (stratified, wellmixed, frontal or Wadden Sea). The overall MDS ordination provided a good representation of the species similarity matrix indicated by a low stress value of 0.09 . While all of the stations in stratified waters showed high species similarities of $>62 \%$, all other predefined groups showed a much lower level of similarity. The $\mathrm{W}$ stations in particular were scattered over a wider geographic area and most of them had only a similarity between 38 and $51 \%$ (the lowest category). This can be explained by the much lower number of species ( 1 to 4 species) at comparatively low abundance encountered at those stations. Therefore, changes in abundance of just 1 or 2 species have a higher impact than in stations with higher diversity. Stations in the stratified areas consistently showed higher numbers in species (8 to 13) with a compara- ble range of abundant species (sardine, sprat, horse mackerel and solenette). Interestingly, one $\mathrm{W}$ station (P18) had a high resemblance (>51\%) to S stations that also had a comparable number of species (9). This station was situated in the Elbe estuary where tidal currents, especially close to the bottom, can be particularly strong (Mittelstaedt et al. 1983). The occurrence of species typical for stratified areas (e.g. sardine, sprat, horse mackerel and solenette) likely indicates the recent advection of more saline waters at depth, even though this could no longer be detected in the accompanying CTD cast. Dynamic interactions among water masses are common in the inner German Bight where changes in the strengths of tidal currents, river discharge, and wind-driven surface currents affect the location and strength of the river plume front and other water masses (Dippner 1993). Eddy detachment from the front (Dippner 1990) and subsequent tidal advection may have transported those larvae to the river mouth, where potential survival of these 'expatriated' larvae may be considered as low.

The importance of the estuaries and nearshore waters along the eastern coast of the southern North Sea as a nursery area for various flatfish species such as plaice Pleuronectes platessa and flounder Platichthys flesus has been recognized for a century (Johansen 1913, 1922, Taning 1943, 1951). In the Wadden Sea, conditions are thought to be favorable for growth and survival due the high productivity of these estuarine areas and the low predation rates due the apparent lack of large predators (Kuipers 1977, van der Veer et al. 2001). At the time of our sampling, no flatfish larvae were captured in the Wadden Sea stations. Plaice and European flounder spawn from January to March and from March to April, respectively (Ehrenbaum 1936, Aurich 1941, Pethon 2005). At the time of our sampling, juveniles would have already settled to benthic, nearshore habitats (Aurich 1941, Rijnsdorp et al. 1985), and would not have been captured using our methods. The 3 flatfish species caught in the offshore areas in this study (solenette, scaldfish and dab) spawn offshore and do not use shallow coastal nursery areas (Creutzberg et al. 1978, Rijnsdorp et al. 1985, van der Veer 1985, Baltus \& van der Veer 1995).

The typical representative for the Wadden Sea in the present study was the lesser pipefish, which also contributed the most to between-station similarities. Another typical species for Wadden Sea assemblages is the garfish, which was found only once in the M and $\mathrm{W}$ stations due to the (as previously discussed) possible underrepresentation of ichthyoneuston. Both 
species utilize macrophytes (e.g. eelgrass) for spawning and nursery areas) (Polte \& Asmus 2006, Korzelecka-Orkisz et al. 2005) and the lack of macrophytes in deeper waters of the North Sea effectively limits potentially successful habitats for the early life stages of these species. For fish species with larvae that utilize nearshore or estuarine habitats, preventing the export of early life stages from these regions is a prerequisite for survival (Johnson \& Gonor 1982). The lesser pipefish adults migrate to shallow coastal areas in spring for reproduction (Hiddink \& Jager 2002), utilizing macrophyte meadows for foraging and predator refuge, and exhibit specialized parental care in which larvae emerge from a male brood pouch as independent free-swimming young (Fiedler 1954, Haresign \& Shumway 1981).

Our June to July sampling indicated that anchovy larvae were absent from offshore and stratified areas and only utilized coastal areas. Aurich (1953) described a similar distribution pattern for anchovy larvae in the same area. The preference of this species for higher temperatures may be responsible for its occurrence in the mixed but warmer areas of the German Bight (Aurich 1953). Survey data indicate that European sardine and anchovy dramatically increased in the southern North Sea in the mid 1990s (Beare et al. 2004, Petitgas et al. 2012) and spawning activity of sardine and anchovy in the North Sea was detected during the cruises made in 2003 to 2004 as part of the German GLOBEC program (M. Peck, pers. obs.). Episodes of increased abundance of anchovy and sardine in the North Sea have been previously documented for 1948 to 1952 and 1958 to 1960 (Aurich 1953, Postuma 1978) and these cycles of increased abundance are likely related to long-term climate cycles and ongoing climate change affecting water temperature and circulation patterns (Rijnsdorp et al. 2009). Aurich (1953) concluded that anchovy was more associated with mixed warm coastal waters with no particular preference to certain salinities, while sardine eggs and larvae appeared to be more restricted to more saline (>32-33) waters at considerably cooler temperatures. The results of this and a companion study that reported biochemical condition (RNA:DNA values) of sprat, anchovy and sardine larvae (see Kanstinger \& Peck 2009), suggest a degree of habitat partitioning between North Sea anchovy and sardine, which utilize near- and offshore areas, respectively.

Frontal zones are prominent features structuring the plankton community and trophodynamics in the North Sea (Kiørboe et al. 1988, Riegman et al. 1990, Munk 1993, Valenzuela \& Vargas 2002). The haline (river plume) and the thermal (tidal mixing) fronts are often found in close proximity to one another, forming a complex frontal system (Simpson et al. 1993). These frontal systems are known to have important consequences for the distribution and abundance of ichthyoplankton due to advection and retention processes. For example, North Sea fronts have been reported to influence the distribution of both autumn-spawned herring and spring-spawned sprat (Kiørboe et al. 1988, Munk 1993). Kanstinger \& Peck (2009) reported that stratified and frontal areas contained significantly larger clupeid larvae than well-mixed areas and similar trends were reported in this study, additionally also for solenette and horse mackerel. These patterns in spatial distribution suggest that the transitional (well-mixed) water masses supported lower rates of growth and survival in larval fish and/or partial retention in the inner German Bight of offshore hatched larvae during ontogeny in species such as sprat, sardine, horse mackerel and solenette. Particularly stratified areas adjacent to tidal fronts seem to offer favorable stable conditions for larval survival (Bakun \& Parrish 1991). Retention in those areas of the inner German Bight could be facilitated under certain weather conditions with northern to southeasterly winds (Mittelstaedt et al. 1983) as well as westerly winds (Dippner 1993). The importance of retention of fish larvae in favorable areas for recruitment has been thoroughly discussed by Sinclair (1988).

Movements from the nearshore environment to offshore and vice versa are generally considered to be either passive or to result from specific behaviors (e.g. vertical migration) or residence within convergence areas associated with internal waves (Shanks 1983, Kingsford \& Choat 1986). For example, the larvae of fishes that utilize the same offshore spawning habitat may display different distributions due to interspecific differences in behavior or developmental physiology that alter larval drift trajectories (Bolle et al. 2009, Peck et al. 2009). Larvae were, however, not evenly distributed within the frontal structure. A discontinuous distribution of larvae within haline frontal zones has been previously reported (e.g. Govoni \& Grimes 1992, Munk \& Wright 2002), and might be caused by both a discontinuous spawning pattern and the character of the physical/biological processes involved in the formation of patches.

\section{Conclusions}

The results of our early summer ichthyoplankton sampling suggest that fronts are associated with a 
distinct division in the larval fish community, separating near- and offshore areas. However, frontal dynamics can also lead to displacement of offshore fish larvae to nearshore, presumably unfavorable areas. Continued, simultaneous monitoring of both near- and offshore habitats is recommended to better understand habitat partitioning by marine fishes in the southern North Sea. This may be particularly important if we hope to understand how anthropogenic activities may influence the survival of fish early life stages and the productivity of the fish community, key elements to building robust spatial management plans for this dynamic region (e.g. Stelzenmüller et al. 2010).

Acknowledgements. We thank the captains and crews of the German RVs 'Alkor' and 'Ludwig Prantl' for their help during sampling. In particular we thank Centre for Materials and Coastal Research (GKSS) and especially G. Flöser for allowing us to use the facilities of the RV 'Ludwig Prandtl'. K. Thomsen, A.-K. Lüders, B. Kleinschmidt, V. Knab, S. Endlich, and M. Kroll helped with plankton sorting. Funding for this research was made available from the German GLOBEC program (BMBF [German Federal Ministry for Research], www.globec-germany.de) and RECONN (DFG [German Science Foundation], DFG \# JO556 1/2).

\section{LITERATURE CITED}

Aurich HJ (1941) Die Verbreitung der pelagischen Fischbrut in der südlichen Nordsee während der Frühjahrsfahrten 1926-1937 der deutschen Forschungsschiffe 'Poseidon' und 'Makrele'. Helgol Wiss Meeresunters 2:183-225

Aurich HJ (1953) Verbreitung und Laichverhältnisse von Sardelle und Sardine in der südöstlichen Nordsee und ihre Veränderungen als Folge der Klimaänderung. Helgol Wiss Meeresunters 4:175-204

$>$ Bakun A, Parrish RH (1991) Comparative studies of coastal pelagic fish reproductive habitats: the anchovy (Engraulis anchoita) of the southwestern Atlantic. ICES J Mar Sci 48:343-361

> Baltus CAM, van der Veer HM (1995) Nursery areas of solenette Buglossidium luteum (Risso, 1810) and scaldfish Arnoglossus laterna (Walbaum, 1792) in the southern North Sea. J Sea Res 34:81-87

> Baumann H, Malzahn AM, Voss R, Temming A (2009) The German Bight (North Sea) is a nursery area for both locally and externally produced sprat juveniles. J Sea Res 61:234-243

Beare D, Burns F, Jones E, Peach K and others (2004) An increase in the abundance of anchovies and sardines in the north-western North Sea since 1995. Glob Change Biol 10:1209-1213

Bolle LJ, Dickey-Collas M, van Beek JKL, Erftemeijer PLA, Witte JIJ, van der Veer HW, Rijnsdorp AD (2009) Variability in transport of fish eggs and larvae. III. Effects of hydrodynamics and larval behaviour on recruitment in plaice. Mar Ecol Prog Ser 390:195-211

Bückmann A (1950) Die Untersuchungen der biologischen Anstalt über die Ökologie der Heringsbrut in der süd- lichen Nordsee. Helgol Wiss Meeresunters 3:1-57

Budéus G (1989): Frontal variability in the German Bight. Scient Mar 53:175-185

Clarke KR, Gorley RN (2006) PRIMER v6: User Manual/ Tutorial. PRIMER-E, Plymouth

Clarke KR, Warwick RM (2001) Change in marine communities. An approach to statistical analysis and interpretation, 2nd edn. PRIMER-E, Plymouth

Creutzberg F, Eltink AT, Van Noort GJ (1978) The migration of plaice larvae Pleuronectes platessa into the western Wadden Sea. In: McLusky DS, Berry AJ (eds) Physiology and behaviour of marine organisms. Proc 12th Europ Mar Biol Symp, Pergamon Press, New York, NY, p 243-251

Dick S, Kleine E, Müller-Navarra S, Klein H, Komo H (2001) The operational circulation model of BSH (BSHcmod). Model description and validation. Berichte des Bundesamtes für Seeschifffahrt und Hydrographie 29/2001, Hamburg

> Dippner JW (1990) Eddy-resolving modelling with dynamically active tracers. Cont Shelf Res 10:87-101

> Dippner JW (1993) A frontal-resolving model for the German Bight. Cont Shelf Res 13:49-66

Ehrenbaum E (1936) Naturgeschichte und wirtschaftliche Bedeutung der Seefische Nordeuropas. Handbuch der Seefischerei Nordeuropas 2, Schweizerbart, Stuttgart

> Fiedler K (1954) Vergleichende Verhaltensstudien an Seenadeln, Schlangennadeln und Seepferdchen (Syngnathidae). Z Tierpsychol 11:358-416

$>$ Fox CJ, Taylor M, Dickey-Collas M, Fossum P and others (2008) Mapping the spawning grounds of North Sea cod (Gadus morhua) by direct and indirect means. Proc Biol Sci 275:1543-1548

Govoni JJ, Grimes CB (1992) The surface accumulation of larval fishes by hydrodynamic convergence within the Mississippi plume front. Cont Shelf Res 12:1265-1276

Greve W, Prinage S, Zidowitz H, Nast J, Reiners F (2005) On the phenology of North Sea ichthyoplankton. ICES J Mar Sci 62:1216-1223

Halbeisen H-W (1988) In der Überarbeitung von Schöfer W: Bestimmungsschlüssel für Fischlarven der Nordsee und angrenzender Gebiete. Report No. 178, Institut für Meereskunde, Kiel

Haresign TH, Shumway SE (1981) Permeability of the marsupium of the pipefish Syngnathus fuscus to $\left[{ }^{14} \mathrm{C}\right]$-alpha amino isobutyric acid. Comp Biochem Physiol 69(A): 603-604

> Hiddink JG, Jager Z (2002) Abundance and reproduction of Nilsson's pipefish on tidal flats. J Fish Biol 61:125-137

> Hillgruber N, Kloppmann M (2001) Small-scale patterns in distribution and feeding of Atlantic mackerel (Scomber scombrus L.) larvae in the Celtic Sea with special regard to intra-cohort cannibalism. Helgol Mar Res 55:135-149

Johansen AC (1913) Contribution in the biology of the plaice, with special regard to the Danish plaice fishery. VI. On the immigration of plaice to the coastal grounds and fjords on the west coast of Jutland. Meddr Kommn Havunders (Ser Fiskeri) 4:1-26

Johansen AC (1922) On the density of the young plaice population in the eastern part of the North Sea and the Skagerrak in the pre-war and in post-war years. Meddr Kommn Havunders (Ser Fiskeri) 6:1-31

John HC (1983): Quantitative distribution of fry of beloniform fishes in the Atantic Ocean. Meteor Forsch Ergebnisse D 36: 21-33 
Johnson GE, Gonor JJ (1982) The tidal exchange of Callianassa californiensis (Crustacea, Decapoda) larvae between the ocean and the Salmon River Estuary, Oregon. Estuar Coast Shelf Sci 14:501-516

Kanstinger P, Peck MA (2009) Co-occurrence of European sardine (Sardina pilchardus), anchovy (Engraulis encrasicolus) and sprat (Sprattus sprattus) larvae in southern North Sea habitats: abundance, distribution and biochemical-based condition. Sci Mar 73S1: $141-152$

Kingsford MJ, Choat JH (1986) Influence of surface slicks on the distribution and onshore movement of small fish. Mar Biol 91:161-172

Kiørboe T, Munk P, Richardson K, Christensen V, Paulsen H (1988) Plankton dynamics and larval herring growth, drift and survival in a frontal area. Mar Ecol Prog Ser 44:205-219

Kloppmann M (1994) Kleinskalige Vertikalverteilung von Fischlarven bei Helgoland. PhD thesis, University of Hamburg

Kloppmann MHF, Bailey MC, Westernhagen Hv (2001) Distribution of larval, post-larval and juvenile mackerel in the Celtic Sea and Porcupine Bank area. ICES CM $2001 / \mathrm{J}: 24$

Korzelecka-Orkisz A, Formicki K, Winnicki A, Bonisławska $\mathrm{M}$ and others (2005) Peculiarities of egg structure and embryonic development of garfish (Belone belone L.). Elect J Ichthyol 1:42-53

Kuipers BR (1977) On the ecology of juvenile plaice on a tidal flat in the Wadden Sea. Neth J Sea Res 11:56-91

Malzahn AM, Boersma M (2007) Year-to-year variation in larval fish assemblages of the southern North Sea. Helgol Mar Res 61:117-126

Mittelstaedt E, Lange W, Brockmann C, Soetje KC (1983) Die Strömungen in der Deutschen Bucht. Publ Nr. 2347 , Deutsches Hydrographisches Institut, Hamburg

Munk P (1993) Differential growth of larval sprat Sprattus sprattus across a tidal front in the eastern North Sea. Mar Ecol Prog Ser 99:17-29

Munk P, Nielsen JG (2005) Eggs and larvae of North Sea fishes. Biofolia, Frederiksberg

Munk P, Wright PW (2002) Distribution of the early larval stages of cod, plaice and lesser sandeel across haline fronts in the North Sea. Estuar Coast Shelf Sci 55: 139-149

Munk P, Larsson PO, Danielssen DS, Moksness E (1999) Variability in frontal zone formation and distribution of gadoid fish larvae at the shelf break in the northeastern North Sea. Mar Ecol Prog Ser 177:221-233

Nellen W, Hempel G (1970) Beobachtungen am Ichthyoneuston der Nordsee. Ber Dt Wiss Komm Meeresforsch 21:311-348

Peck MA, Kühn W, Hinrichsen HH, Pohlmann T (2009) Inter-annual and inter-specific differences in the drift of fish eggs and yolksac larvae in the North Sea: a biophysical modeling approach. Sci Mar 73:23-36

Petitgas P, Alheit J, Peck MA, Raab K and others (2012) Anchovy population expansion in the North Sea. Mar Ecol Prog Ser 444:1-13

Pethon P (2005) Aschehougs store fiskebok. 5th edn. H Aschehoug \& Co, Oslo
Polte P, Asmus H (2006) Intertidal seagrass beds (Zostera noltii) as spawning grounds for transient fishes in the Wadden Sea. Mar Ecol Prog Ser 312:235-243

Postuma KH (1978) Immigration of southern fish into the North Sea. Rapp P-V Réun Cons Int Explor Mer 172: 225-229

> Riegman R, Cohjn F, Malschaert JFP, Kloosterhuis HT, Cadee GC (1990) Assessment of growth rate limiting nutrients in the North Sea by the use of nutrient-uptake kinetics. Neth J Sea Res 26:53-60

Rijnsdorp AD, Straten M, van der Veer HW (1985) Selective tidal transport of North Sea plaice Pleuronectes platessa in coastal nursery areas. Trans Am Fish Soc 114:461-470

Rijnsdorp A, Peck MA, Engelhard GH, Möllmann C, Pinnegar JK (2009) Resolving the effect of climate change on fish populations. ICES J Mar Sci 66:1570-1583

Russell FS (1976) The eggs and planktonic stages of British marine fishes. Academic Press, New York, NY

Shanks AL (1983) Surface slicks associated with tidally forced internal waves may transport pelagic larvae of benthic invertebrates and fishes shoreward. Mar Ecol Prog Ser 13:311-315

Simpson JH, Edelsten DJ, Edwards A, Morris NCG, Tett PB (1979) The Islay front: physical structure and phytoplankton distribution. Estuar Coast Mar Sci 9:713-726

Simpson JH, Bos WG, Schirme F, Souza AJ, Rippeth TP, Jones SE, Hydes D (1993) Periodic stratification in the Rhine ROFI in the North Sea. Oceanol Acta 16:23-32

Smith PE, Richardson SL (1977) Standard techniques for pelagic fish egg and larva surveys. Fisheries Technical Paper 175, FAO, Rome

Sinclair M (1988) Marine populations: an essay on population regulation and speciation. Washington Sea Grant Program, Seattle, WA

Somerton DA, Kobayashi DR (1989) A method for correcting catches of fish larvae for the size selection of plankton nets. Fish Bull US 87:447-455

Stelzenmüller V, Jim R, Ellis JR, Rogers SI (2010) Towards a spatially explicit risk assessment for marine management: assessing the vulnerability of fish to aggregate extraction. Biol Conserv 143:230-238

Taning AV (1943) Fluctuation in the number of 0-group plaice fished in the Wadden Sea. Annls Biol Copenh 1:135-137

Taning AV (1951) Occurrence of 0-group plaice in the Danish Wadden Sea. Annls Biol Copenh 7:91-92

Valenzuela GS, Vargas CA (2002) Comparative larval growth rate of Sprattus sprattus in relation to physical and biological oceanographic features in the North Sea. Arch Fish Mar Res 49(Suppl 3):213-230

van der Veer H (1985) Impact of coelenterate predation on larval plaice Pleuronectes platessa and flounder Platichthys flesus stock in the western Wadden Sea. Mar Ecol Prog Ser 25:229-238

van der Veer H, Dapper R, Witte JIJ (2001) The nursery function of the intertidal areas in the western Wadden Sea for 0-group sole Solea solea (L.). J Sea Res 45: 271-279

Wheeler A (1969) The fishes of the British Isles and northwest Europe. Michigan State University Press, East Lansing, MI 
Appendix 1. Stations sampled for fish larvae within southern North Sea habitats during June and July 2005. ID numbers indicate stations sampled from RVs 'Alkor' (A) and 'Ludwig Prandtl'(P). The 36 stations were separated into 4 categories: mixed $(\mathrm{M})$, tidal mixing front $(\mathrm{F})$, stratified $(\mathrm{S})$, and Wadden Sea

(W) based upon water column stability (see 'Materials and methods')

\begin{tabular}{|c|c|c|c|c|c|c|c|}
\hline \multirow{2}{*}{$\begin{array}{l}\text { Station } \\
\text { (ID) }\end{array}$} & \multirow{2}{*}{$\begin{array}{c}\text { Date } \\
\text { (Day } \\
\text { Month) }\end{array}$} & \multirow{2}{*}{$\begin{array}{l}\text { Time } \\
\text { (Hour) }\end{array}$} & \multicolumn{2}{|c|}{ Location } & \multirow{2}{*}{$\begin{array}{l}\text { Max. tow } \\
\text { depth } \\
\text { (m) }\end{array}$} & \multirow{2}{*}{$\begin{array}{c}\text { Volume } \\
\text { filtered } \\
\left(\mathrm{m}^{3}\right)\end{array}$} & \multirow{2}{*}{$\begin{array}{c}\text { Station } \\
\text { category }\end{array}$} \\
\hline & & & $\begin{array}{l}\text { Lat. } \\
\left({ }^{\circ} \mathrm{N}\right)\end{array}$ & $\begin{array}{l}\text { Long } \\
\left({ }^{\circ} \mathrm{E}\right)\end{array}$ & & & \\
\hline A1 & 28 Jun & $4: 30$ & 54.52 & 8.16 & 16 & 206.0 & M \\
\hline $\mathrm{A} 2$ & 28 Jun & $12: 31$ & 54.55 & 7.29 & 32 & 130.1 & $\mathrm{~S}$ \\
\hline A3 & 28 Jun & $15: 37$ & 54.55 & 6.94 & 37 & 114.8 & $\mathrm{~S}$ \\
\hline $\mathrm{A} 4$ & 28 Jun & $13: 04$ & 54.47 & 7.66 & 25 & 250.0 & $\mathrm{~S}$ \\
\hline P5 & 29 Jun & $15: 30$ & 53.72 & 6.33 & 22 & 63.1 & M \\
\hline P6 & 29 Jun & 10:41 & 53.50 & 6.45 & 2 & 23.7 & W \\
\hline P7 & 29 Jun & $11: 50$ & 53.46 & 6.56 & 3 & 22.9 & W \\
\hline P10 & 30 Jun & $15: 36$ & 53.82 & 7.08 & 20 & 26.7 & M \\
\hline P8 & 30 Jun & $7: 56$ & 53.54 & 6.74 & 12 & 26.8 & W \\
\hline P9 & 30 Jun & $9: 56$ & 53.40 & 6.96 & 11 & 28.5 & W \\
\hline A5 & $01 \mathrm{Jul}$ & $16: 13$ & 54.36 & 7.27 & 43 & 211.4 & $\mathrm{~S}$ \\
\hline A6 & $01 \mathrm{Jul}$ & $11: 54$ & 53.99 & 7.20 & 28 & 199.8 & $\mathrm{~F}$ \\
\hline P11 & $01 \mathrm{Jul}$ & $9: 52$ & 53.74 & 7.16 & 5 & 45.4 & W \\
\hline P12 & $01 \mathrm{Jul}$ & $10: 53$ & 53.67 & 7.12 & 7 & 30.6 & W \\
\hline P13 & $01 \mathrm{Jul}$ & $11: 20$ & 53.65 & 7.15 & 2 & 33.5 & W \\
\hline A7 & 02 Jul & $14: 31$ & 54.18 & 7.34 & 38 & 157.1 & $\mathrm{~S}$ \\
\hline A8 & 02 Jul & $16: 29$ & 54.22 & 7.29 & 38 & 57.2 & $\mathrm{~S}$ \\
\hline A9 & 02 Jul & $8: 19$ & 54.09 & 7.18 & 36 & 63.8 & $\mathrm{~S}$ \\
\hline A10 & $04 \mathrm{Jul}$ & $14: 17$ & 54.13 & 8.02 & 28 & 82.9 & $\mathrm{~S}$ \\
\hline P14 & $04 \mathrm{Jul}$ & $12: 40$ & 53.69 & 7.48 & 10 & 41.3 & W \\
\hline P15 & $05 \mathrm{Jul}$ & $17: 17$ & 53.47 & 8.23 & 18 & 10.2 & W \\
\hline A11 & $06 \mathrm{Jul}$ & $8: 44$ & 54.51 & 7.90 & 19 & 157.9 & $\mathrm{~F}$ \\
\hline P16 & $06 \mathrm{Jul}$ & $8: 22$ & 53.71 & 8.07 & 13 & 7.5 & W \\
\hline P17 & $06 \mathrm{Jul}$ & $16: 24$ & 53.53 & 8.57 & 11 & 10.9 & W \\
\hline P18 & $07 \mathrm{Jul}$ & $15: 14$ & 53.87 & 8.71 & 18 & 16.9 & W \\
\hline P19 & 08 Jul & $11: 07$ & 54.08 & 8.54 & 9 & 10.8 & M \\
\hline P20 & $08 \mathrm{Jul}$ & $14: 41$ & 54.12 & 8.86 & 8 & 58.7 & W \\
\hline P21 & $08 \mathrm{Jul}$ & $15: 22$ & 54.12 & 8.78 & 8 & 25.6 & W \\
\hline P22 & $08 \mathrm{Jul}$ & $15: 46$ & 54.11 & 8.86 & 8 & 44.0 & W \\
\hline P23 & $09 \mathrm{Jul}$ & $10: 41$ & 54.10 & 8.56 & 9 & 48.8 & M \\
\hline P24 & $09 \mathrm{Jul}$ & $11: 50$ & 54.12 & 8.32 & 10 & 27.8 & $\mathrm{~F}$ \\
\hline P25 & $09 \mathrm{Jul}$ & $15: 15$ & 54.18 & 7.89 & 40 & 41.1 & $\mathrm{~S}$ \\
\hline P1 & $10 \mathrm{Jul}$ & $16: 01$ & 54.44 & 8.77 & 11 & 29.8 & W \\
\hline P2 & $11 \mathrm{Jul}$ & $13: 03$ & 54.44 & 8.89 & 3 & 31.3 & W \\
\hline P3 & $12 \mathrm{Jul}$ & $10: 52$ & 54.68 & 8.60 & 11 & 31.3 & W \\
\hline $\mathrm{P} 4$ & $12 \mathrm{Jul}$ & $11: 38$ & 54.70 & 8.64 & 9 & 39.4 & W \\
\hline
\end{tabular}

Editorial responsibility: Christine Paetzold, Oldendorf/Luhe, Germany
Submitted: July 11, 2011; Accepted: February 21, 2012

Proofs received from author(s): May 14, 2012 